CLINICAL STUDY

\title{
Interleukin-18 in plasma and adipose tissue: effects of obesity, insulin resistance, and weight loss
}

\author{
Jens M Bruun, Bente Stallknecht ${ }^{1}$, Jørn W Helge ${ }^{1}$ and Bjørn Richelsen \\ Department of Endocrinology and Metabolism C, Aarhus University Hospital, Aarhus Sygehus, DK-8000 Aarhus C, Denmark and ${ }^{1}$ Copenhagen Medical \\ Research Centre, Department of Medical Physiology, The Panum Institute, University of Copenhagen, DK-2200 Copenhagen N, Denmark \\ (Correspondence should be addressed to J M Bruun; Email: Jens.Bruun@ki.au.dk)
}

\begin{abstract}
Objective: Interleukin (IL)-18 is associated with obesity, insulin resistance, and cardiovascular disease. The present study compared 1) IL-18 in adipocytes versus stromal vascular (SV) cells, 2) IL-18 in plasma and adipose tissue (AT) in obese versus lean subjects, and 3) IL-18 in plasma, AT, and skeletal muscle (SM) in obese subjects after weight loss.

Subjects and methods: At baseline, plasma and AT IL-18 in 23 obese subjects were compared with that in 12 lean subjects. The obese subjects were submitted to a 15-week life-style intervention (hypocaloric diet and daily exercise) after which plasma samples, AT, and SM biopsies were obtained. Analyses were performed by ELISA and RT-PCR respectively.

Results: IL-18 expression in isolated adipocytes was $\sim 2 \%$ of that in SV cells. Plasma IL-18 was higher in obese subjects $(P<0.001)$ and associated with insulin resistance (HOMA; $P<0.001)$. AT expression of IL-18, CD14, and CD68 was higher in obese $(P<0.01)$. The intervention reduced body weight $(P<0.001)$, plasma IL-18 $(P<0.001)$, and increased insulin sensitivity (HOMA; $P<0.05)$. AT and SM expression of IL-18 remained unchanged after the intervention. Changes in plasma IL-18 were associated with changes in insulin sensitivity $(P<0.05)$ but not with BMI or AT expression of IL-18. Conclusion: Plasma IL-18 is associated with changes in insulin resistance and reduced after weight loss. AT expression of IL-18 is increased in obesity but not affected by weight loss, indicating that changes in plasma IL-18 are related to insulin resistance rather than changes in obesity per se.
\end{abstract}

European Journal of Endocrinology 157 465-471

\section{Introduction}

Visceral obesity is a chronic low-grade inflammatory state associated with the development of insulin resistance, type 2 diabetes, and cardiovascular disease (1). The background for the obesity-related low-grade inflammation remains unknown but human adipose tissue (AT) is characterized by the ability to produce and release a variety of inflammatory proteins, collectively known as adipokines: e.g. adiponectin (2), tumor necrosis factor (TNF)- $\alpha$ (3), interleukin (IL)-6 (4), IL-8 (5), and monocyte chemoattractant protein (MCP)-1 (6). With increasing adiposity, human AT is infiltrated by monocytes and macrophages in both s.c. AT (7) and visceral AT (8). Only adiponectin and leptin are adipocyte specific, and inflammatory cells (e.g. monocytes and macrophages) within the stromal vascular (SV) fraction primarily account for the production of several of the other known adipokines $(8,9)$.

IL-18 is found to be produced and released from human AT and isolated adipocytes in vitro (10-12) as well as from skeletal muscle (SM) (13). As for the majority of the other known adipokines, IL-18 production primarily originates from the non-fat cells within the AT $(14,15)$. IL-18 is a $18.3 \mathrm{kDa}$ proinflammatory cytokine belonging to the IL-1 family (16), displaying chemoattractant properties by inducing mononuclear cell recruitment and thereby inflammation in vitro and in vivo (17). Low-grade inflammation seems to be a central feature in several metabolic diseases, and plasma IL-18 is found to be elevated in obesity (18), in women with polycystic ovary syndrome (19), and in patients with type 2 diabetes $(20,21)$. In addition, IL-18 is expressed in the atherosclerotic plaque and involved in atherogenesis $(22-24)$ as well as associated with plaque instability and cardiovascular death $(23,25,26)$. Weight loss induced by diet (18) or bariatric surgery (27) induces a significant reduction in plasma IL-18, but so far only few investigations have evaluated whether the reduction in plasma IL-18 is paralleled by a decrease in IL-18 mRNA expression in human AT.

The present study is an extension of a previously published study (28) with focus on IL-18 in order to (1) compare AT IL-18 mRNA expression in the adipocyte fraction with that in the SV fraction; (2) investigate the 
possible differences in IL-18 in plasma and AT in lean and obese subjects; and (3) investigate the effects of weight loss induced by a 15 -week life-style intervention on IL-18 in plasma, AT, and SM as well as the relationship with adiposity (body mass index (BMI), $\mathrm{kg} / \mathrm{m}^{2}$ ), homeostasis model of insulin resistance (HOMA), macrophage/monocyte specific markers (CD68 and CD14), and various adipokines (adiponectin, IL-6, IL-8, TNF- $\alpha$, and MCP-1).

\section{Subjects and methods}

\section{Subjects}

The present study is divided into three sub-studies as follows:

Study 1. An in vitro comparison between isolated adipocytes and SV cells obtained from s.c. abdominal AT from six normal to overweight women (mean age: $31.0 \pm 5.4$ years, mean BMI: $24.0 \pm 1.8 \mathrm{~kg} / \mathrm{m}^{2}$ ) undergoing liposuction for cosmetic reasons.

Study 2. A cross-sectional baseline investigation comparing plasma levels of IL-18 in 12 lean subjects (four females and eight males; mean age: $32.0 \pm 3.0$ years, mean BMI: $22.8 \pm 0.5 \mathrm{~kg} / \mathrm{m}^{2}$ ) with that in 23 obese subjects (12 females and 11 males; mean age: $32.2 \pm 1.9$ years, mean BMI: $45.8 \pm 1.9 \mathrm{~kg} / \mathrm{m}^{2}$ ) and AT-mRNA levels of IL-18, CD14, and CD68 in four lean subjects (two females and two males; mean age: $30.3 \pm 4.5$ years, mean BMI: $23.3 \pm 0.9 \mathrm{~kg} / \mathrm{m}^{2}$ ) to that of 19 obese subjects (ten females and nine males; mean age: $33.5 \pm 2.1$ years, mean BMI: $47.4 \pm 2.0 \mathrm{~kg} / \mathrm{m}^{2}$ ).

Study 3. A weight loss study described in detail in (28), investigating the effect of the 15-week life-style intervention (hypocaloric diet and moderate daily physical activity) on plasma levels of IL-18 in 23 obese subjects (12 females and 11 males; mean age: $32.2 \pm 1.9$ years, mean BMI: $45.8 \pm 1.9 \mathrm{~kg} / \mathrm{m}^{2}$ ), AT-mRNA levels of IL-18 in 19 obese subjects (ten females and nine males; mean age: $33.5 \pm 2.1$ years, mean BMI: $47.4 \pm 2.0 \mathrm{~kg} / \mathrm{m}^{2}$ ), and SM-mRNA levels of IL-18 in 14 obese subjects (seven females and seven males; mean age: $32.3 \pm 2.2$ years, mean BMI: $48.0 \pm 2.1 \mathrm{~kg} / \mathrm{m}^{2}$ ). The association between IL-18 and various anthropometrical and inflammatory markers was also investigated, elaborating on previous findings reported in (28).

All subjects included in the three sub-studies were Caucasian. None of the subjects in the in vitro study (study 1) and none of the lean subjects (study 2) received any medication. In the intervention study (study 3), five of the obese subjects were treated for hypertension (with calcium channel blockers, angiotensin-I-converting enzyme inhibitors, or angiotensin-II receptor blockers), four were treated for asthma (inhalation only), and five received oral contraceptives, but all received the same dose and type of medication throughout the study.

\section{Preparation of isolated adipocytes and SV cells}

As described in (5), AT was transported to the laboratory and washed several times in isotonic saline. Adipocytes were isolated by collagenase digestion $(0.15 \mathrm{mg} / \mathrm{g} \mathrm{AT})$ of AT fragments in $10 \mathrm{mmol} / \mathrm{l} \mathrm{HEPES}$ buffer for $45-60 \mathrm{~min}$ at $37^{\circ} \mathrm{C}$. The isolated adipocytes were washed three times in buffer containing 5\% albumin and resuspended in medium 199 containing $1 \%$ BSA and $25 \mathrm{mM}$ HEPES. Finally, $200 \mu \mathrm{l}$ cell suspension containing $10 \%$ adipose cells $(\sim 100000$ adipocytes) were aliquoted in separate tubes and snapfrozen in liquid nitrogen and kept at $-80{ }^{\circ} \mathrm{C}$ until RNA extraction. After the initial collagenase digestion, the remaining SV fraction was centrifuged for $15 \mathrm{~min}$ at $6300 \mathrm{~g}$, resuspended in $9 \mathrm{ml}$ buffer, and filtered through a nylon mesh. This procedure was repeated three times after which the supernatant was removed, and the SV fraction was snap-frozen in liquid nitrogen and kept at $-80{ }^{\circ} \mathrm{C}$ until RNA extraction.

\section{AT and SM biopsies}

AT samples from 4 lean and 19 obese subjects were obtained from the s.c., abdominal AT depot at the level of the umbilicus as previously described (5). In brief, the skin was anesthetized with lidocaine $(10 \mathrm{mg} / \mathrm{ml})$ before a small incision was made and $\sim 200 \mathrm{mg}$ AT were removed under sterile conditions. Immediately after removal, the AT sample was washed in isotonic saline and snap-frozen in liquid nitrogen and kept at $-80^{\circ} \mathrm{C}$ until RNA extraction. SM samples were obtained from the vastus lateralis muscle. Skin and muscle fascia were anesthetized with lidocaine $(5 \mathrm{mg} / \mathrm{ml})$ and under sterile conditions, a $1 \mathrm{~cm}$ incision was made and $\sim 100 \mathrm{mg}$ muscle tissue were removed using the Bergström technique. Immediately after removal, the muscle biopsy was dissected free of visible fat and snap-frozen in liquid nitrogen and kept at $-80^{\circ} \mathrm{C}$ until RNA extraction.

\section{Determination of inflammatory markers in plasma}

Plasma samples were measured using specific highsensitive human ELISA. The IL-18 assay (Quantikine, R\&D Systems Europe Ltd, Abingdon, UK) had an intraassay coefficient of variation $(\mathrm{CV})$ of $7.3 \%(n=5)$. The adiponectin assay (B-Bridge International Inc., San Francisco, CA, USA) had an intra-assay CV of $5.0 \%$ $(n=12)$. The IL-8 assay (Quantiglo, R\&D Systems Europe Ltd) had an intra-assay CV of $6.4 \%(n=12)$. The IL-6 assay (Quantikine HS600, R\&D Systems Europe Ltd) had an intra-assay CV of $5.5 \%(n=12)$. The TNF- $\alpha$ assay (Quantikine HSTA00C, R\&D Systems Europe Ltd) had an intra-assay CV of 3.5\% $(n=12)$. The MCP-1 assay (R\&D Systems Europe Ltd) had an intraassay $\mathrm{CV}$ of $8.1 \%(n=12)$. 


\section{Determination of mRNA levels}

RNA was isolated using Trizol reagent (Gibco BRL, Life Technologies) and cDNA was made with random hexamer primers using the GeneAmp PCR kit (Applied Biosystems, Foster City, CA, USA). The following oligonucleotide primer pairs were used: IL-18: $5^{\prime}$-GCTTGAATCTAAATTATCAGTC-3', 5'-GAAGATTCAAATTGCATCTTAT-3'; CD14: 5'-TAAAGGACTGCCAGCCAAGC3', 5'-AGCCAAGGCAGTTTGAGTCC-3'; CD68: 5'-GCTACATGGCGGTGGAGTACAA-3', 5'-ATGATGAGAGGCAGCAAG ATGG-3'; TNF- $\alpha$ : 5'-CGAGTGACAAGCCTGTAGC-3', 5'-GGTGTGGGTGAGGAGC-ACAT-3'; IL-6: 5'AAATGCCAGCCTGCTGACGAAG-3', 5'-AACAACAATCT-GAGGTGCCCATGCTAC-3'; IL-8: 5'-TTGGCAGCCTTCCTGA TTTC-3', 5'-AACTTCTCCACAACCCTCT-G-3'; MCP-1: 5'-CGACATCCTGGAACTGCCCTACC-3', 5'CACTGTGCCGCTCTCGTTCAC-3 ${ }^{\prime}$; adiponectin: 5'-CATGACCAGGAAACCACGACT-3', 5'-TGAATGCTGAGCGGTAT-3'; $\beta$-actin: 5'-ACGGGGTCACCCACACTGTGC-3', 5'-CTAGAAGCATTTGCGGTGGACGATG-3'. The mRNA levels of the target genes were expressed relative to the housekeeping gene ( $\beta$-actin). The expression of $\beta$-actin was unchanged before and after the intervention (threshold cycles $\left(C_{\mathrm{T}}\right): 25.3 \pm 0.3$ vs $24.9 \pm 0.3$; $P=0.29)$. Quantification was performed with a SYBRGreen real-time PCR assay using an iCycler PCR machine (Bio-Rad Laboratories Inc). In brief, PCR amplification was performed with PCR Mastermix containing target primers, HotStar Taq DNA polymerase, SYBR-Green, and PCR buffer. All samples were determined as duplicates. Samples were incubated for an initial denaturation at $95^{\circ} \mathrm{C}$ for $10 \mathrm{~min}$, followed by 40 PCR cycles each consisting of $95^{\circ} \mathrm{C}$ for $30 \mathrm{~s}, 57^{\circ} \mathrm{C}$ for $30 \mathrm{~s}$, and $74^{\circ} \mathrm{C}$ for $60 \mathrm{~s}$. Relative gene expression of target gene to $\beta$-actin was calculated as described in User Bulletin no. 2, 1997 from Perkin-Elmer (Perkin-Elmer Cetus, Norwalk, CT, USA).

\section{Statistical analysis}

The SigmaStat 3.1 statistical packet (Systat Software Inc., Point Richmond, CA, USA) was used for the calculations. Normality of distribution was tested using the Kolmogorov-Smirnov test. All anthropometrical and metabolic parameters were found to be normally distributed. AT IL-18 was found not to be normally distributed when a Mann-Whitney rank sum test was applied for comparing mRNA levels in the adipocyte fraction with that in the SV fraction. IL-18 in plasma and AT was found not to be normally distributed when a Mann-Whitney rank sum test was applied for examining the relationship at baseline between lean and obese subjects. IL-18 in plasma, AT, and SM was found not to be normally distributed when a Mann-Whitney rank sum test was applied for comparing circulating levels of IL-18, and IL-18 mRNA levels in AT- and SM biopsies before and after the intervention. A bivariate correlation analysis with a Pearson correlation coefficient $\left(r_{\mathrm{p}}\right)$ was used to investigate the possible relationship between metabolic and inflammatory markers at baseline as well as changes in these parameters after the intervention. Values are presented as mean \pm s.e.m. Threshold for significance was set at $P<0.05$.

\section{Ethics}

Informed, written consent was obtained from all subjects, and experiments were performed in accordance with the Helsinki II Declaration. The study was approved by the Ethical Committees of Aarhus and Copenhagen.

\section{Results}

\section{Isolated adipocytes versus SV cells}

In general, a low expression of IL-18 mRNA was found in the AT biopsies. After separation (by collagenase digestion) of the adipocyte and SV fraction, it was found that IL-18 mRNA expression in the adipocyte fraction was only $\sim 2 \%$ of that in the SV fraction $(P<0.05)$.

\section{IL-18 in lean and obese subjects}

Circulating levels of IL-18 was higher in obese subjects compared with lean $(243.3 \pm 20.3$ vs $141.9 \pm$ $19.7 \mathrm{pg} / \mathrm{ml} ; P<0.001$, Fig. 1). IL-18 mRNA expression was significantly higher in AT biopsies from obese compared with lean $(P<0.01$, Fig. 2$)$. As a marker for macrophage infiltration in the AT, mRNA expression of CD14 and CD68 was found to be higher in obese compared with lean $(6.3 \pm 1.4$ vs $0.2 \pm 0.1$ arbitrary units, $P<0.01$, and $0.43 \pm 0.08$ vs $0.02 \pm 0.01$ arbitrary units, $P<0.01)$. No gender difference in IL-18 was found in neither plasma $(P=0.58$, data not shown $)$ nor in AT $(P=0.96$, data not shown).

\section{Effects of weight loss}

As described in detail in (28), the 15-week intervention reduced body weight by $\sim 18 \mathrm{~kg} \quad(138.3 \pm 5.9$ vs $120.7 \pm 5.4 \mathrm{~kg} ; P<0.001)$, BMI $(45.8 \pm 1.9$ vs $\left.40.0 \pm 1.8 \mathrm{~kg} / \mathrm{m}^{2} ; P<0.001\right)$, waist circumference $(142.6 \pm 4.0$ vs $132.2 \pm 4.2 \mathrm{~cm} ; P<0.001)$, and total body fat mass $(46.0 \pm 2.5$ vs $41.4 \pm 2.3 \mathrm{~kg} ; P<0.001)$. In parallel, insulin sensitivity was improved according to an OGTT $(P<0.001)$ and HOMA (HOMA = fasting insulin $\times$ fasting glucose/22.5) (29) $(P<0.05)$. No significant difference was observed in the blood pressure (systolic BP: $131.1 \pm 2.7$ vs $128.6 \pm 2.7 \mathrm{mmHg}$; diastolic BP: $83.8 \pm 2.3$ vs $79.2 \pm 3.0 \mathrm{mmHg}$ ).

The intervention reduced circulating IL-18 by $22 \%$ $(243.3 \pm 20.3$ vs $190.9 \pm 10.1 \mathrm{pg} / \mathrm{ml} ; P<0.001$, Fig. 1$)$ 


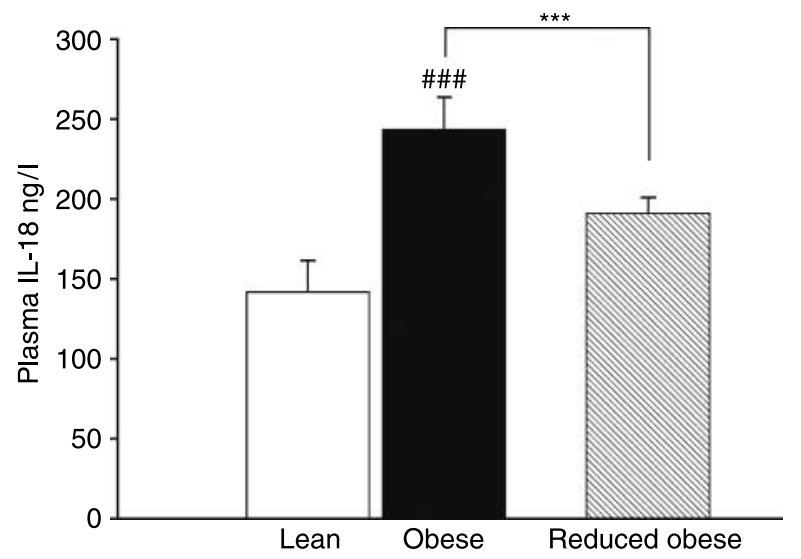

Figure 1 Plasma IL-18 in lean versus obese and in reduced obese. Plasma IL-18 (ng/l) was assessed at baseline in 12 lean (white bar) and in 23 obese subjects (black bar). After weight loss induced by a 15-week life-style intervention (hypocaloric diet and daily exercise), plasma IL-18 was assessed again in the 23 obese subjects (shaded bar). Data represent mean values \pm s.E.M. \#\#\#P<0.001 (lean versus obese) and ${ }^{* * *} P<0.001$ (obese versus reduced obese)

but was without effect on IL-18 mRNA expression in AT (Fig. 2) and SM (Fig. 3).

\section{Correlations between IL-18 and metabolic and inflammatory parameters}

At baseline, plasma IL-18 in obese subjects correlated significantly with BMI $(P<0.01)$ and HOMA $(P<0.001)$ but not with AT IL-18, CD14, or CD68 mRNA expression (Table 1). Plasma IL-18 did not correlate with waist circumference or various inflammatory parameters (e.g. TNF- $\alpha$, IL-6, adiponectin, MCP1 , and IL-8; data not shown). HOMA correlated significantly with BMI $\left(r_{\mathrm{p}}=0.71 ; P<0.001\right.$, data not shown). At baseline, AT IL-18 mRNA expression did not correlate with HOMA, CD14 or CD68 (Table 1) in

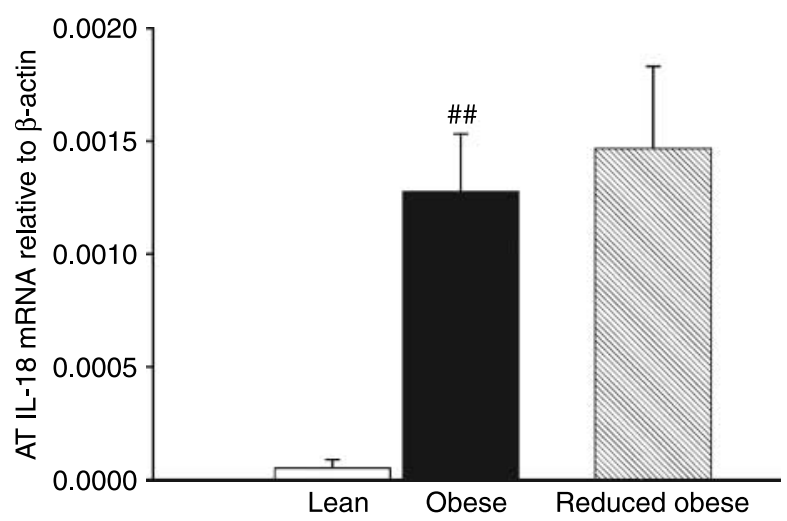

Figure 2 IL-18 mRNA expression in adipose tissue. IL-18 mRNA expression was assessed in s.c. abdominal adipose tissue biopsies obtained from 4 lean (white bar) and 19 obese subjects (black bar). After weight loss induced by a 15-week life-style intervention (hypocaloric diet and daily exercise), IL-18 mRNA expression was assessed again in the 19 obese subjects (shaded bar). Data represent mean values \pm s.E.m. \#\#P<0.01 (lean versus obese). addition to various inflammatory proteins known to be expressed in human AT (e.g. TNF- $\alpha$, IL-6, adiponectin, MCP-1, and IL-8; data not shown). After the 15-week intervention, changes in plasma IL-18 ( $\Delta$ plasma IL-18) correlated significantly with $\triangle$ HOMA $(P<0.05)$ but not with $\triangle$ BMI $(P=0.27)$ or $\triangle$ AT IL-18 mRNA $(P=0.33)$. $\triangle$ HOMA correlated with $\triangle$ BMI $\left(r_{\mathrm{p}}=0.54 ; P<0.05\right.$, data not shown). Interestingly, when using a multiple stepwise regression analysis, $\triangle$ HOMA was found to be the main (and significant) predictor $(P<0.05)$ and $\Delta \mathrm{BMI}$ to be a non-significant $(P=0.08)$ predictor of $\Delta \mathrm{IL}$ 18. Neither $\Delta$ plasma IL-18 nor $\Delta$ AT IL-18 mRNA correlated with $\Delta$ CD14, $\Delta$ CD68, $\Delta$ TNF- $\alpha, \Delta$ IL-6, $\Delta$ adiponectin, $\Delta \mathrm{MCP}-1$, or $\Delta \mathrm{IL}-8 \mathrm{mRNA}$ (data not shown; Table 2).

\section{Discussion}

The present study is an extension of a previously published study (28) with novel findings on IL-18 in plasma and AT. Plasma IL-18 and AT IL-18 expressions were found to be increased in obese when compared with lean subjects. Plasma IL-18 at baseline and after the 15-week life-style intervention correlated significantly with insulin resistance (HOMA) but not with BMI or AT IL-18 expression, in accordance with the findings in a multiple stepwise regression analysis where changes in HOMA were found to be the main (and significant) predictor of changes in plasma IL- 18 . Finally, the 15-week life-style intervention significantly reduced plasma IL-18 but was without effect on IL-18 mRNA expression in AT and SM from the same obese subjects.

IL-18 is reported to be expressed in human AT (10-12) and SM (13). In accordance, we found IL-18 to be expressed in AT and SM of severely obese subjects but did not observe any effect of weight loss. In our human AT samples, mRNA expression of IL-18 was primarily found in the SV fraction with only $\sim 2 \%$ in the

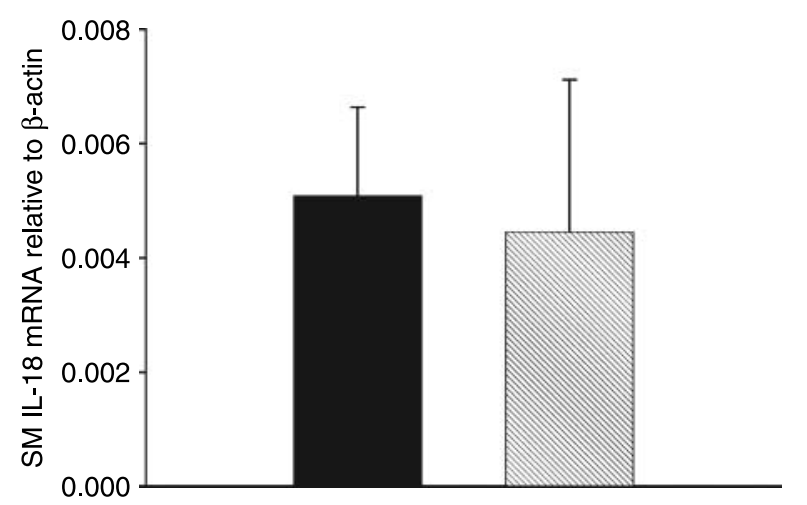

Figure $3 \mathrm{IL}-18$ mRNA expression in skeletal muscle. IL-18 mRNA expression in skeletal muscle biopsies was assessed at baseline in 12 obese subjects (black bar) and again after weight loss induced by a 15-week life-style intervention (hypocaloric diet and daily exercise) in the same 12 subjects (shaded bar). 
Table 1 Baseline correlations between interleukin (IL)-18 in plasma and adipose tissue (AT) and metabolic and inflammatory parameters.

\begin{tabular}{lcccc}
\hline & $\begin{array}{c}\text { Plasma } \\
\text { IL-18 }\end{array}$ & $\boldsymbol{P}$ & $\begin{array}{c}\text { AT IL-18 } \\
\text { mRNA }\end{array}$ & $\boldsymbol{P}$ \\
\hline Plasma IL-18 & ND & & $r_{\mathrm{p}}=0.22$ & 0.31 \\
BMI & $r_{\mathrm{p}}=0.49$ & $<0.01$ & $r_{\mathrm{p}}=0.30$ & 0.16 \\
HOMA & $r_{\mathrm{p}}=0.65$ & $<0.001$ & $r_{\mathrm{p}}=0.28$ & 0.21 \\
AT CD14 mRNA & $r_{\mathrm{p}}=0.35$ & 0.11 & $r_{\mathrm{p}}=0.12$ & 0.59 \\
AT CD68 mRNA & $r_{\mathrm{p}}=0.31$ & 0.15 & $r_{\mathrm{p}}=0.30$ & 0.16 \\
\hline
\end{tabular}

adipocyte fraction confirming findings by Clement et al. (14) and Fain et al. (15). Even though IL-18 mRNA was higher in obese compared with the lean subjects, a relatively low AT-mRNA expression was found in the present study in accordance with previous reports $(10,11)$. Although Wood et al. were unable to detect IL-18 protein in the medium from isolated human adipocytes incubated up to $24 \mathrm{~h}$ (11), two recent studies have reported release of IL-18 protein from isolated human mammary adipocytes (12) and, whole human AT cultures (15). However, in both studies, IL-18 protein release was $\sim 1000$ times lower than the protein release of IL- 8 and IL-6 (5, 30). This indicates that AT-derived IL-18 is of minor or no importance to plasma IL-18 levels. However, IL-18 may exert autocrine or paracrine pro-inflammatory effects within the AT via release of IL- 8 and IL-1 $\beta$ through a TNF- $\alpha$ dependent mechanism in monocytes (31). At the same time, lipopolysaccharide can induce IL-18 expression in monocytes (32) and TNF- $\alpha$ can induce IL-18 expression in isolated adipocytes in vitro (11) but not in AT in vivo (13). These interactions between IL-18 and other pro-inflammatory adipokines within the AT may create a vicious circle leading to a final net release of pro-inflammatory proteins to the circulation.

Esposito et al. were the first to link high plasma levels of IL-18 to obesity (18). We found plasma IL-18 to be significantly correlated with BMI, thus confirming this finding. In addition, we elaborated on the findings by Esposito et al. by parallel AT biopsies and found a significant increase in IL-18 mRNA expression in the AT from obese compared with the lean subjects confirming recent findings by Leick et al. (33). IL-18 is attracting increasing interest since plasma IL-18 is found to be associated with metabolic and cardiovascular diseases such as obesity (18), polycystic ovary syndrome (19), type 2 diabetes $(20,21)$, lipodystrophy (34), atherogenesis (22-24), and plaque instability $(23,26,35)$.

Table 2 Correlations between changes in plasma interleukin (IL)18 and metabolic and inflammatory parameters.

\begin{tabular}{lcr}
\hline & $\Delta$ plasma IL-18 & \multicolumn{1}{c}{$\boldsymbol{P}$} \\
\hline$\Delta$ AT IL-18 mRNA & $r_{\mathrm{p}}=0.24$ & 0.33 \\
$\Delta$ BMI & $r_{\mathrm{p}}=0.24$ & 0.27 \\
$\Delta$ HOMA & $r_{\mathrm{p}}=0.50$ & $<0.05$ \\
\hline
\end{tabular}

The underlying cause of the association between plasma IL-18 and the development of cardiovascular disease seems to be through an IL-18-induced inflammatory cell recruitment (17) and subsequent induction of macrophage-derived interferon- $\gamma$, TNF- $\alpha$, IL-6, IL-8, and IL-1 $\beta$ within the atherosclerotic plaque $(22,31)$.

In the present paper, a 15-week life-style intervention consisting of hypocaloric diet and supervised daily moderate physical activity significantly reduced plasma levels of IL-18. This finding is essentially in line with other studies, in which a weight loss induced reduction in plasma IL-18 was obtained through hypocaloric diet (1300 kcal/day) and behavioral counseling in 40 obese women (18) or bariatric surgery (27). Interestingly, plasma IL-18 is reported to be associated with traits of the metabolic syndrome (BMI, waist circumference, triglyceride, high-density lipoprotein (inversely), fasting glucose, and insulin) in a dose-dependent manner but independent of obesity (36). This report is in line with two recent papers, in which increased plasma IL-18 was associated with the development of type 2 diabetes independent of fat mass $(21,37)$. We found plasma IL18 to be correlated with both HOMA and BMI at baseline but interestingly the changes in plasma IL-18 ( $\Delta$ plasma IL-18) after the 15 -week intervention was only correlated with $\triangle$ HOMA and not with $\Delta \mathrm{BMI}$. These findings may suggest that plasma IL-18 is more related to the degree of insulin sensitivity/insulin resistance than to obesity per se. Recently, clamp-induced hyperglycemia $(15 \mathrm{mmol} / \mathrm{l})$ was reported to increase plasma IL-18 (38), indicating that weight loss as reported in the present study and other studies may decrease plasma IL-18 through an improvement in insulin sensitivity rather than a reduction in obesity. In addition to hyperglycemia and insulin resistance, obesity is associated with a low-grade inflammation suggested to involve an increased infiltration of macrophages/monocytes in the AT $(7,8)$. In accordance, we found a significant increase in macrophage/ monocyte infiltration in the AT obtained from our population of severely obese subjects $(\mathrm{BMI}=47.4)$ as compared with our population of lean subjects $(\mathrm{BMI}=$ 23.3). The significant weight loss obtained after the 15-week intervention has previously been demonstrated to decrease mRNA expression of CD14 and CD68 (28), but this attenuation of AT inflammation was found to be without an effect on AT IL-18 mRNA expression in the present study. This is in contrast to a recent study by Leick et al. in which an 8-week exercise program tended to $(P=0.06)$ reduce AT IL-18 expression (33). However, in contrast to the present study Leick et al. did not find any change in plasma IL-18, body weight, or insulin sensitivity as assessed by HOMA after the intervention.

In conclusion, plasma IL-18 and AT-mRNA expressions of IL-18, CD14, and CD68 are increased in obese compared with lean subjects. A 15-week combination of hypocaloric diet and regular moderate 
physical activity induced an increase in insulin sensitivity paralleled by a decrease in plasma IL-18 but was without effect on AT expression of IL-18. This is of specific interest since IL-18 in whole human AT samples as well as in isolated adipocytes, and the adjacent SV fraction only displayed very low expression levels. The findings in the present paper suggest that the increase in plasma IL-18 in obesity is associated with the degree of insulin sensitivity rather than obesity per se and that AT-derived IL-18 may be of only minor importance in obesity-related low-grade inflammation.

\section{Acknowledgements}

We thank subjects and staff at Ebeltoft Kurcenter for participating in the study. We highly appreciate the expert technical assistance of Lenette Pedersen, Pia Hornbek, and Regitze Kraunsøe. Finally, we thank Jane Østergaard Pedersen and Esther Zimmermann for performing the anthropometrical measurements and assisting the subjects on the days of the experiments.

\section{Funding}

The study was supported by the Novo Nordic Foundation, Konsul J Fogh-Nielsens Legat and The Danish Medical Research Council (22-02-0527 to J M B).

\section{References}

1 Dandona P, Aljada A \& Bandyopadhyay A. Inflammation: the link between insulin resistance, obesity and diabetes. Trends in Immunology 200425 4-7.

2 Arita Y, Kihara S, Ouchi N, Takahashi M, Maeda K, Miyagawa J, Hotta K, Shimomura I, Nakamura T, Miyaoka K, Kuriyama H, Nishida M, Yamashita S, Okubo K, Matsubara K, Muraguchi M, Ohmoto Y, Funahashi T \& Matsuzawa Y. Paradoxical decrease of an adipose-specific protein, adiponectin, in obesity. Biochemical and Biophysical Research Communication 1999257 79-83.

3 Hotamisligil GS, Arner P, Caro JF, Atkinson RL \& Spiegelman BM. Increased adipose tissue expression of tumor necrosis factor-alpha in human obesity and insulin resistance. Journal of Clinical Invesigation 199595 2409-2415.

4 Fried SK, Bunkin DA \& Greenberg AS. Omental and subcutaneous adipose tissues of obese subjects release interleukin-6: depot difference and regulation by glucocorticoid. Journal of Clinical Endocrinology and Metabolism $1998 \mathbf{8 3} 847-850$.

5 Bruun JM, Pedersen SB \& Richelsen B. Regulation of interleukin 8 production and gene expression in human adipose tissue in vitro. Journal of Clinical Endocrinology and Metabolism $2001 \mathbf{8 6}$ 1267-1273.

6 Gerhardt CC, Romero IA, Cancello R, Camoin L \& Strosberg AD. Chemokines control fat accumulation and leptin secretion by cultured human adipocytes. Molecular and Cellular Endocrinology 2001175 81-92.

7 Weisberg SP, McCann D, Desai M, Rosenbaum M, Leibel RL \& Ferrante AW Jr. Obesity is associated with macrophage accumulation in adipose tissue. Journal of Clinical Invesigation 2003112 1796-1808.
8 Bruun JM, Lihn AS, Pedersen SB \& Richelsen B. Monocyte chemoattractant protein-1 release is higher in visceral than subcutaneous human adipose tissue (AT). Implication of macrophages resident in the AT. Journal of Clinical Endocrinology and Metabolism 200590 2282-2289.

9 Fain JN, Cheema PS, Bahouth SW \& Lloyd HM. Resistin release by human adipose tissue explants in primary culture. Biochemical and Biophysical Research Communication 2003300 674-678.

10 Lindegaard B, Hansen AB, Pilegaard H, Keller P, Gerstoft J \& Pedersen BK. Adipose tissue expression of IL-18 and HIVassociated lipodystrophy. AIDS 200418 1956-1958.

11 Wood IS, Wang B, Jenkins JR \& Trayhurn P. The pro-inflammatory cytokine IL-18 is expressed in human adipose tissue and strongly upregulated by TNFalpha in human adipocytes. Biochemical and Biophysical Research Communication $2005337422-429$.

12 Skurk T, Kolb H, Muller-Scholze S, Rohrig K, Hauner H \& Herder C. The proatherogenic cytokine interleukin- 18 is secreted by human adipocytes. European Journal of Endocrinology 2005 152 863-868.

13 Krogh-Madsen R, Plomgaard P, Moller K, Mittendorfer B \& Pedersen BK. Influence of TNF-alpha and IL-6 infusions on insulin sensitivity and expression of IL-18 in humans. American Journal of Physiology Endocrinology and Metabolism 2006291 E108-E114.

14 Clement K, Viguerie N, Poitou C, Carette C, Pelloux V, Curat CA, Sicard A, Rome S, Benis A, Zucker JD, Vidal H, Laville M, Barsh GS, Basdevant A, Stich V, Cancello R \& Langin D. Weight loss regulates inflammation-related genes in white adipose tissue of obese subjects. FASEB Journal 200418 1657-1669.

15 Fain JN, Tichansky DS \& Madan AK. Most of the interleukin 1 receptor antagonist, cathepsin S, macrophage migration inhibitory factor, nerve growth factor, and interleukin 18 release by explants of human adipose tissue is by the non-fat cells, not by the adipocytes. Metabolism 200655 1113-1121.

16 Gillespie MT \& Horwood NJ. Interleukin-18: perspectives on the newest interleukin. Cytokine \& Growth Factor Reviews 19989 $109-116$.

17 Komai-Koma M, Gracie JA, Wei XQ, Xu D, Thomson N, McInnes IB \& Liew FY. Chemoattraction of human T cells by IL-18. Journal of Immunology 2003170 1084-1090.

18 Esposito K, Pontillo A, Ciotola M, Di Palo C, Grella E, Nicoletti G \& Giugliano D. Weight loss reduces interleukin-18 levels in obese women. Journal of Clinical Endocrinology and Metabolism 200287 3864-3866.

19 Escobar-Morreale HF, Botella-Carretero JI, Villuendas G, Sancho J \& San Millan JL. Serum interleukin-18 concentrations are increased in the polycystic ovary syndrome: relationship to insulin resistance and to obesity. Journal of Clinical Endocrinology and Metabolism 200489 806-811.

20 Esposito K, Nappo F, Giugliano F, Di Palo C, Ciotola M, Barbieri M, Paolisso G \& Giugliano D. Cytokine milieu tends toward inflammation in type 2 diabetes. Diabetes Care 2003261647.

21 Thorand B, Kolb H, Baumert J, Koenig W, Chambless L, Meisinger C, Illig T, Martin S \& Herder C. Elevated Levels of Interleukin-18 Predict the development of type 2 diabetes: results from the MONICA/KORA Augsburg Study, 1984-2002. Diabetes $2005542932-2938$.

22 Gerdes N, Sukhova GK, Libby P, Reynolds RS, Young JL \& Schonbeck U. Expression of interleukin (IL)-18 and functional IL18 receptor on human vascular endothelial cells, smooth muscle cells, and macrophages: implications for atherogenesis. Journal of Experimental Medicine 2002195 245-257.

23 Mallat Z, Corbaz A, Scoazec A, Besnard S, Leseche G, Chvatchko Y $\&$ Tedgui A. Expression of interleukin-18 in human atherosclerotic plaques and relation to plaque instability. Circulation $2001 \mathbf{1 0 4}$ 1598-1603.

24 Hulthe J, McPheat W, Samnegard A, Tornvall P, Hamsten A \& Eriksson P. Plasma interleukin (IL)-18 concentrations is elevated in patients with previous myocardial infarction and related to severity of coronary atherosclerosis independently of C-reactive protein and IL-6. Atherosclerosis $2006 \mathbf{1 8 8} 450-454$. 
25 Mallat Z, Henry P, Fressonnet R, Alouani S, Scoazec A, Beaufils P, Chvatchko Y \& Tedgui A. Increased plasma concentrations of interleukin-18 in acute coronary syndromes. Heart $2002 \mathbf{8 8}$ 467-469.

26 Blankenberg S, Tiret L, Bickel C, Peetz D, Cambien F, Meyer J \& Rupprecht HJ. Interleukin-18 is a strong predictor of cardiovascular death in stable and unstable angina. Circulation $2002 \mathbf{1 0 6}$ 24-30.

27 Schernthaner GH, Kopp HP, Kriwanek S, Krzyzanowska K, Satler M, Koppensteiner R \& Schernthaner G. Effect of massive weight loss induced by bariatric surgery on serum levels of interleukin-18 and monocyte-chemoattractant-protein-1 in morbid obesity. Obesity Surgery 200616 709-715.

28 Bruun JM, Helge JW, Richelsen B \& Stallknecht B. Diet and exercise reduce low-grade inflammation and macrophage infiltration in adipose tissue but not in skeletal muscle in severely obese subjects. American Journal of Physiology Endocrinology and Metabolism 2006 290 E961-E967.

29 Haffner SM, Miettinen H \& Stern MP. The homeostasis model in the San Antonio Heart Study. Diabetes Care $1997201087-1092$.

30 Fain JN, Madan AK, Hiler ML, Cheema P \& Bahouth SW. Comparison of the release of adipokines by adipose tissue, adipose tissue matrix, and adipocytes from visceral and subcutaneous abdominal adipose tissues of obese humans. Endocrinology 2004 $1452273-2282$.

31 Puren AJ, Fantuzzi G, Gu Y, Su MS \& Dinarello CA. Interleukin-18 (IFNgamma-inducing factor) induces IL-8 and IL-1beta via TNFalpha production from non-CD14+ human blood mononuclear cells. Journal of Clinical Invesigation 1998 $101711-721$.

32 Marshall JD, ste-Amezaga M, Chehimi SS, Murphy M, Olsen H \& Trinchieri G. Regulation of human IL-18 mRNA expression. Clinical Immunology $19999015-21$.
33 Leick L, Lindegaard B, Stensvold D, Plomgaard P, Saltin B \& Pilegaard H. Adipose tissue interleukin-18 mRNA and plasma interleukin-18: effect of obesity and exercise. Obesity 200715 356-363.

34 Lindegaard B, Hansen AB, Gerstoft J \& Pedersen BK. High plasma level of interleukin-18 in HIV-infected subjects with lipodystrophy. Journal of Acquired Immune Deficiency Syndromes $2004 \mathbf{3 6}$ 588-593.

35 de Nooijer R, von der Thusen JH, Verkleij CJ, Kuiper J, Jukema JW, van der Wall EE, van Berkel TJ \& Biessen EA. Overexpression of IL-18 decreases intimal collagen content and promotes a vulnerable plaque phenotype in apolipoprotein-e-deficient mice. Arteriosclerosis, Thrombosis and Vascular Biology 200424 2313-2319.

36 Hung J, McQuillan BM, Chapman CM, Thompson PL \& Beilby JP. Elevated interleukin-18 levels are associated with the metabolic syndrome independent of obesity and insulin resistance. Arteriosclerosis, Thrombosis and Vascular Biology 200525 1268-1273.

37 Herder C, Baumert J, Kolb H, Koenig W, Martin S \& Thorand B. Circulating levels of interleukin-18 independent of body fat and fat-free mass: results from the MONICA/KORA study. Diabetes Care $200629174-175$.

38 Esposito K, Nappo F, Marfella R, Giugliano G, Giugliano F, Ciotola M, Quagliaro L, Ceriello A \& Giugliano D. Inflammatory cytokine concentrations are acutely increased by hyperglycemia in humans: role of oxidative stress. Circulation $2002 \mathbf{1 0 6}$ 2067-2072.

Received 28 March 2007

Accepted 12 July 2007 